\title{
Dietary fish oil did not prevent sleep deprived rats from a reduction in adipose tissue adiponectin gene expression
}

\author{
Ana Barbosa Marcondes de Mattos ${ }^{1}$, Mônica Jordão S Pinto ${ }^{1}$, \\ Cristiane Oliveira ${ }^{1}$, Carolina Biz ${ }^{1}$, Eliane Beraldi Ribeiro ${ }^{1}$, Claudia Maria \\ Oller do Nascimento ${ }^{1}$, Monica Levy Andersen ${ }^{2}$, Sergio Tufik ${ }^{2}$ and
} Lila Missae Oyama*3,4

Address: ${ }^{1}$ Department of Physiology, Federal University of São Paulo, São Paulo, Brazil, ${ }^{2}$ Department of Psychobiology, Federal University of São Paulo, São Paulo, Brazil, ${ }^{3}$ Department of Bioscience, Federal University of São Paulo, Santos, Brazil and ${ }^{4}$ Universidade Federal de São Paulo, UNIFESP, Departamento de Fisiologia Rua Botucatu, 862, $2^{\circ}$ andar, Vila Clementino, São Paulo, SP, Brazil

Email: Ana Barbosa Marcondes de Mattos - anamattos9@hotmail.com; Mônica Jordão S Pinto - monijordao@hotmail.com; Cristiane Oliveira - crisoliva@ hotmail.com; Carolina Biz - carolbiz@unifesp.br; Eliane Beraldi Ribeiro - eliane.beraldi@unifesp.br; Claudia Maria Oller do Nascimento - claudia.oller@unifesp.br; Monica Levy Andersen - mandersen@psicobio.epm.br; Sergio Tufik - stufik@psicobio.epm.br; Lila Missae Oyama* - lmoyama@unifesp.br

* Corresponding author

Published: 5 November 2008

Lipids in Health and Disease 2008, 7:43 doi:10.1186/1476-5IIX-7-43

This article is available from: http://www.lipidworld.com/content/7///43

(C) 2008 de Mattos et al; licensee BioMed Central Ltd.

This is an Open Access article distributed under the terms of the Creative Commons Attribution License (http://creativecommons.org/licenses/by/2.0), which permits unrestricted use, distribution, and reproduction in any medium, provided the original work is properly cited.
Received: I September 2008

Accepted: 5 November 2008

\begin{abstract}
Sleep deprivation in humans has been related to weight gain and consequently, increased risk for insulin resistance. In contrast, there is a significant loss of weight in sleep deprived rats suggesting a state of insulin resistance without obesity interference. Thus, we aimed to assess the effects of a rich fish oil dietetic intervention on glucose tolerance, serum insulin and adiponectin, and adipose tissue gene expression of adiponectin and TNF- $\alpha$ of paradoxically sleep deprived (PSD) rats. The study was performed in thirty day-old male Wistar randomly assigned into two groups: rats fed with control diet (soybean oil as source of fat) and rats fed with a fish oil rich diet. After 45 days of treatment, the animals were submitted to PSD or maintained as home cage control group for $96 \mathrm{~h}$. Body weight and food intake were carefully monitored in all groups. At the end of PSD period, a glucose tolerance test was performed and the total blood and adipose tissues were collected. Serum insulin and adiponectin were analyzed. Adipose tissues were used for RT-PCR to estimate the gene expression of adiponectin and TNF- $\alpha$. Results showed that although fish oil diet did not exert any effect upon these measurements, PSD induced a reduction in adiponectin gene expression of retroperitoneal adipose tissues, with no change in serum adiponectin concentration or in adiponectin and TNF- $\alpha$ gene expression of epididymal adipose tissue. Thus, the stress induced by sleep deprivation lead to a desbalance of adiponectin gene expression.
\end{abstract}

\section{Introduction}

The constant search of more time to achieve all daily activities has leaded the major part of world population to deprive some of the sleep hours [1]. The real conse- quences of this change are still not totally known, but studies have been pointing out for a range of metabolic and hormonal alterations, which unbalance and damage the normal function of the body [2-8]. Nevertless, the 
population is sleeping 1.5 hours less than a century ago [9]. It seems that this reduction in sleep, which was directly associated with advanced age, has been imposed to the young age with the increase of demand and life style of modern society [10]. Indeed, young people are exposing their health to the development of alterations, which can lead to an increase in the incidence of age-related diseases earlier and with unknown intensity.

Studies indicate that sleep deprivation causes an autonomic desbalance $[11,12]$ with an impairment of the negative feedback control of hypotalamic-pituitary-adrenal axis [13-18,8]. Plasma cortisol is altered over 24 hour of day, predisposing to insulin resistance development $[19,2,20]$. Furthermore, Spiegel et al [3] proposed that it can be either by direct effect on the components of glucose regulation, or by indirect effect, through the deregulation of appetite, leading to a weight gain and obesity seeing in humans.

Recent prospective studies have shown long term consequences associated with alterations of chronic sleep deprivation, demonstrating a direct correlation between the duration of sleep and Diabetes type 2 incidence [21$24,9,25]$. In fact, sleep deprivation is an environment important factor in the development of insulin resistance (for review see [26]), as well as different types of diets can influence, in terms of improvement or impairment, the insulin sensitivity.

While the wide range of fat acids has been related with the increase in risk for insulin resistance, the long chain polyunsaturated fat acid omega-3, found in large quantity in fish oil, has been pointed as insulin sensitizing, [27-32]. Moreover, although the mechanisms involved are not totally understood, adiponectin seems to have an important role in this positive effect $[30,33,31]$. Thus, our study aimed to assess the effects of fish oil rich dietetic intervention on glucose tolerance, serum insulin and adiponectin, and adipose tissue gene expression of adiponectin and TNF- $\alpha$ in paradoxically sleep deprived rats.

\section{Materials and methods \\ Animals and treatments}

Forty-eight male Wistar rats aged 30 days and weighting 100-150 g were obtained from Federal University of São Paulo Experimental Models Development Center (CEDEME). The rats were housed inside standard polypropylene cages in a temperature-controlled $\left(23 \pm 1^{\circ} \mathrm{C}\right)$ room with a 12:12 h light-dark cycle (lights on at 07:00 hours). All procedures used in the present study complied with the guidelines established by Ethical and Practical Principles of the Use of Laboratory Animals [34]. This study was approved by Federal University of São Paulo Research Ethics Committee (01419/06).

Rats were fed with rich fish oil $(\mathrm{n}=24)$ or control diet ( $\mathrm{n}$ $=24$ ) since they were weaned. At 75 days-old, the animals were randomly distributed in 4 different groups: homecage control with normal diet (CTRL, $\mathrm{n}=12$ ); home-cage fish oil diet (CTRL+D, $\mathrm{n}=12)$; paradoxical sleep deprived control fed with normal diet (PSD, $\mathrm{n}=12$ ), and paradoxically sleep deprived with fish oil diet (PSD+D, $\mathrm{n}=12)$.

Both diets were prepared according to the recommendations of the American Institute of Nutrition (AIN-93G and AIN-93M) [35], being similar in calories and lipid content (see table 1). The source of lipids for the control diet was soybean oil (Liza, Brazil) and in the fish oil diet was fish oil (Campestre, Brazil). Diet components were casein (Labsynth, Brazil), L-cystine, cornstarch, butylated hydroxytoluene, cellulose and choline bitartrate (Vitafarm, Brazil) and AIN-93 mineral mixture and vitamin mixture (Dyets Inc, USA).

\section{Paradoxical Sleep deprivation}

The rats were submitted to single platform PSD platform method, which involved placing the animal on a narrow

Table I: Experimental diet compositions according to AIN-93G- growth diet and AIN-93M- maintenance diet

\begin{tabular}{|c|c|c|c|c|}
\hline \multirow[t]{2}{*}{ INGREDIENT } & \multirow{2}{*}{$\begin{array}{c}\text { CONTROL DIET (g// } 00 \mathrm{~g}) \\
\text { AIN-93 G }\end{array}$} & \multicolumn{3}{|c|}{ FISH OIL DIET (g/l $00 \mathrm{~g})$} \\
\hline & & AIN-93 M & AIN-93 G & AIN-93 M \\
\hline Casein & 20 & 14 & 20 & 14 \\
\hline L-cistine & 0.3 & 0.18 & 0.3 & 0.18 \\
\hline Cornstarch & 62 & 71.1 & 62 & 71.1 \\
\hline Soybean oil & 8 & 5 & - & - \\
\hline Fish oil & - & - & 8 & 5 \\
\hline Butylated hydroxytoluene & 0.0014 & 0.0008 & 0.0014 & 0.0008 \\
\hline Mineral mixture & 3.5 & 3.5 & 3.5 & 3.5 \\
\hline Vitamin mixture & 1 & 1 & 1 & 1 \\
\hline Cellulose & 5 & 5 & 5 & 5 \\
\hline Choline bitartrate & 0.25 & 0.25 & 0.25 & 0.25 \\
\hline
\end{tabular}


circular platform $(6.5 \mathrm{~cm}$ in diameter $)$ placed inside a chamber filled with water to within $1 \mathrm{~cm}$ of their upper surface over a period of 96 hours. At the onset of each PS episode, the animal experiences a loss of muscle tone and falls into the water, thus being awakened. The period of $96 \mathrm{~h}$ of PSD was chosen since our previous data showed that the most dramatic alterations in lipid $[36,37]$ and hormone [17] concentrations occur at this time point. Food and water were provided ad libitum by placing chow pellets and water bottles on a grid located on top of the chamber. The basis of the feeder was adapted with a plate to avoid pieces of chow falling into the water. The water in the chambers was changed daily throughout the PSD period. Control rats were placed inside the water chamber but, instead of water, the chamber was filled with sawdust. All rats were habituated to their experimental environment for $3 \mathrm{~h}, 6 \mathrm{~h}$ and $12 \mathrm{~h}$, respectively, on the 3 days preceding the onset of the experiment.

\section{Glucose Tolerance Test}

Twelve hours before the end of PSD, the animals were deprived of food for $12 \mathrm{~h}(10 \mathrm{am}$ to $10 \mathrm{pm})$. At the $96 \mathrm{~h}$ of PSD or equivalent period in control rats, all animals were anesthetized with ketamine/xilazine (66.6/13.3 mg/ $\mathrm{Kg}$ ). The inguinal cavity was exposed and the femoral artery was canulated for the glucose tolerance test. Initially the baseline blood was collected to assess basal glucose and insulin. Then the glucose load $(750 \mathrm{mg} / \mathrm{Kg}$ of body weight) was administrated and blood was collected after $4,12,20,24,28$ and 32 minutes to measure glucose concentration. The total blood was collected and maintained in a $-80^{\circ} \mathrm{C}$ freezer until assays with ELISA commercial kits for insulin and adiponectin.

\section{Carcass lipid and protein content}

Carcasses were eviscerated, weighed, and stored at $-20^{\circ} \mathrm{C}$. Lipid content was measured as described by Stansbie et al [38] and standardized using the method described by Oller do Nascimeto and Williamson [39]. Briefly, the eviscerated carcass was autoclaved at $120^{\circ} \mathrm{C}$ for 90 minutes and homogenized with double the mass of water. Triplicate aliquots of this homogenate were weighed and digested in $3 \mathrm{ml}$ of $30 \% \mathrm{KOH}$ and $3 \mathrm{ml}$ of ethanol for at least 2 hours at $70^{\circ} \mathrm{C}$ in capped tubes. After cooling, $2 \mathrm{ml}$ of $12 \mathrm{~N} \mathrm{H}_{2} \mathrm{SO}_{4}$ were added and the sample was washed three times with petroleum ether for lipid extraction. Results are expressed as grams of lipid per $100 \mathrm{~g}$ of carcass. For protein measurements, aliquots of the same homogenate were heated to $37^{\circ} \mathrm{C}$ for 1 hour in $0.6 \mathrm{~N} \mathrm{KOH}$ with constant shaking. After clarification by centrifugation, protein content was measured according to the method described by Lowry et al [40].

\section{Real Time polymerase chain reaction}

Adiponectin and TNF- $\alpha$ mRNA from retroperitoneal adipose tissue (RET) and epididymal adipose tissue (EPI) was quantified by Real Time Polymerase chain reaction (PCR). RNA samples were previously treated with DNAse (DNAfree, Promega, USA). One microgram of each sample was reverse transcribed using an M-MLV Reverse Transcriptase kit (Promega, USA), and cDNA was synthesized in a final volume of $50 \mu \mathrm{L}$. The relative level of Adiponectin and TNF- $\alpha$ mRNA was quantified in real time, using SYBR Green primer in an ABI Prism 7700 Sequence detector (both from Applied Biosystems, USA). The relative level of the housekeeping gene hypoxanthine phosphoribosyltransferase (HPRT) was measured. The primers used were: Adiponectin, 5' GAAGTAGACTCTGCTGAGATGG-3' (sense) and 5' TATCAGTGTAGGAGGTCTGTGATG-3' (antisense); TNF- $\alpha$, 5'CGCTCTTCTGTCTACTGAAC3' (sense) e 5'TTCTCCAGCTGGAAGACTCC3'(antisense) and HPRT, 5'CTCATGGACTGATTATGGACAGGA3' (sense) and 5'GCAGGTCAGCAAAGAACTTATAGC3' (antisense).

Results were obtained using sequence detector Software (Applied Biosystems, USA) and are expressed as a relative increase, using the method of $2^{\Delta \Delta \mathrm{Ct}}$ described by Livak and Schmittgen [41].

\section{Biochemical and Hormonal serum analysis}

Serum glucose concentration was measured by an enzymatic colorimetric method using commercial kits (Labtest, Brazil). Serum adiponectin and insulin concentration were quantified using specific enzyme-linked immunosorbent assay (ELISA) kits (Linco Research, USA).

\section{Statistical Analysis}

All results are presented as means \pm standard error of the mean (SE). Statistical significances were assessed using two-way analysis of variance (ANOVA) followed by Duncan's test. Differences were considered significant when $\mathrm{p}$ $<0.05$.

\section{Results}

\section{Body weight gain and food intake}

Body weight and food intake were monitored in all groups of rats throughout the whole experiment period. During the diet treatment period, the total body weight gain was not different between groups (Fig. 1A). After PSD, significant group (CTRL or PSD) effect $\left[F_{(1,39)}=\right.$ 36.97; $\mathrm{p}<0.001$ ] was revealed by two-way ANOVA. The post-hoc Duncan analysis demonstrated that sleep deprivation decreased body weight in both normal and fish oil diet groups ( $\mathrm{p}<0.0001)$, as shown in Fig. 1B. In regards to total food intake, no significant difference was observed between all groups (Fig. 1C).

\section{Carcass fat content}

The results of carcass fat and protein content are depicted in Fig. 2A. There was a significant interaction $\left[F_{(1,49)}=\right.$ $7.52 ; \mathrm{p}<0.009]$ between group and diet, in which PSD 
A

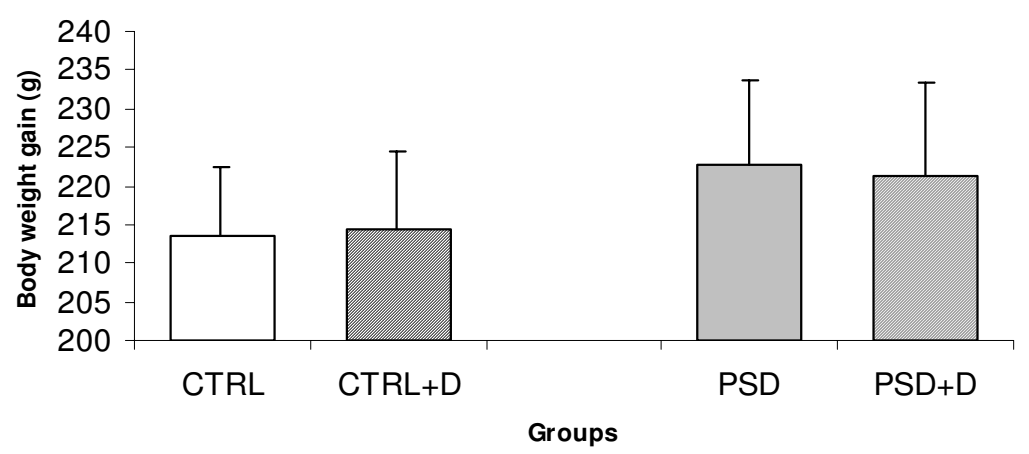

B

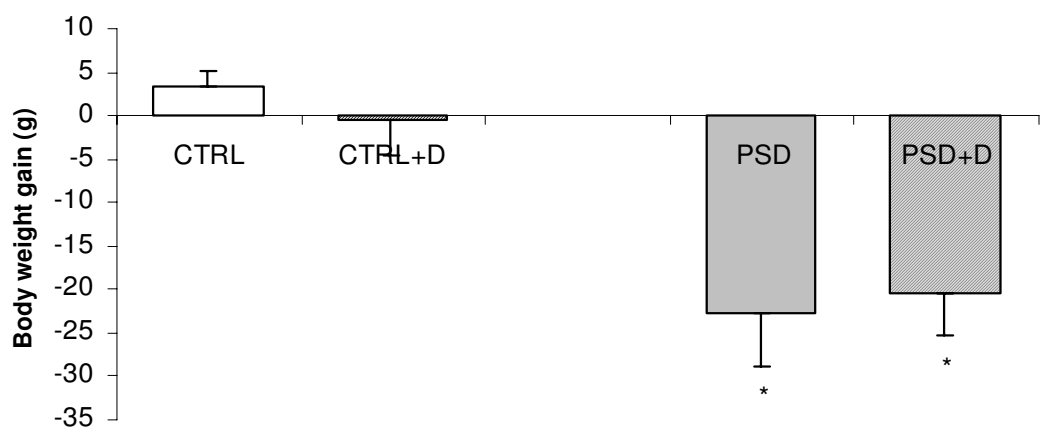

Groups

C

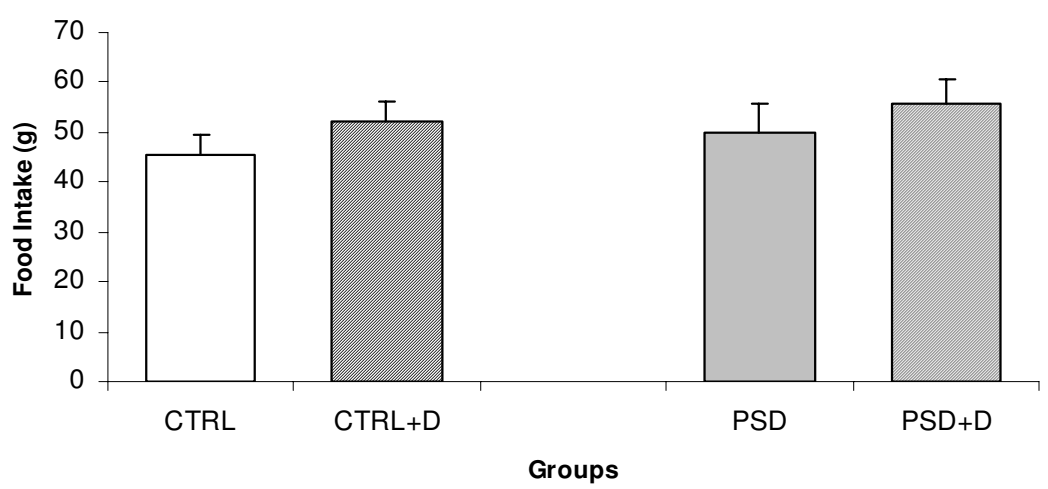

\section{Figure I}

Alterations in total body weight gain (A) during diet treatment and during paradoxical sleep deprivation (B). Figure (C) depicts total food intake (g) measured in control (CTRL) and paradoxical sleep deprived (PSD) rats fed with normal or fish oil diet (D). Data are expressed as mean \pm SEM. *Different from CTRL rats. $N=10-12$ rats/groups. 
rats fed with normal diet exhibited significant decreased fat content in the carcass compared with other groups ( $p$ $<0.03$ ). No significant difference was observed between groups for protein content (Fig. 2B).

\section{Glucose Tolerance test}

The glucose tolerance test showed a group effect $\left[F_{(1,29)}=\right.$ 8.31; $\mathrm{p}<0.007$ ] during the baseline $(\mathrm{p}<0.01), 4^{\circ}$ minute $(\mathrm{p}<0.005), 12^{\circ}$ minute $(\mathrm{p}<0.04), 24^{\circ}$ minute $(\mathrm{p}<$ $0.01), 28^{\circ}$ minute $(\mathrm{p}<0.03)$, and $32^{\circ}$ minute $(\mathrm{p}<$ $0.001)$. Duncan test analysis demonstrated that the glucose in the CTRL group was significantly higher than in PSD group ( $<<0.03)$, independently of the diet for all these time-points. In the $32^{\circ}$ minute of the test, there was also an interaction between group and diet $\left[F_{(1,33)}=4.20\right.$; $\mathrm{p}<0.05]$. The Duncan test revealed that the glucose was significantly lower in $\mathrm{PSD}+\mathrm{D}$ rats than any other group ( $\mathrm{p}$ $<0.01$ ), as depicted in Fig. 3A.

\section{Serum, insulin and adiponectin}

No significant alteration in the serum insulin (Fig. 4) and adiponectin (Fig. 5) was observed in the four groups evaluated.

\section{Quantification of gene expression}

Figure 6 depicts adiponectin and TNF- $\alpha$ gene expression in adipose tissue of all groups. ANOVA revealed a significant group effect $\left[F_{(1,26)}=9.53 ; \mathrm{p}<0.004\right]$. The Duncan test showed that adiponectin gene expression in retroperitoneal adipose tissue was significantly lower in PSD rats compared with CTRL rats ( $<<0.004)$, as shown in Fig. 6A. Further, adiponectin and TNF- $\alpha$ gene expression was not different between all groups in epididymal adipose tissue (Fig. 6B) (Fig.6C).

\section{Discussion}

In the present study we investigated the effect of a fish oil diet prior and during the period of 96 hours of PSD in metabolic parameters involved in insulin resistance of rats. As previously described, sleep deprivation induced a significant loss of weight [42-48] and increased corticosterone concentrations $[49,16,17]$ after $96 \mathrm{~h}$ of PSD protocol, being related to an increased energy expenditure and thus, a negative energy balance. The carcass fat content was lower in sleep deprived rats, as previously reported by Hipolide et al. (2006) while the protein carcass content was not different between groups.

In contrast with previous studies, we found no difference in total food intake. As in our protocol we included an apparatus under the feeders, it may have avoided the waste mentioned recently $[48,50]$. For instance, these authors reported that there was not an increase in food intake in sleep deprived rats, but a stereotyped gnawing behavior that overestimates the food intake as far as they do not have access to food crumps in the platform technique.

Fish oil has been associated to preventing weight loss during severe physical stress [51,52]. However, results herein showed that long-term fish oil diet did not alter body weight. The reasons for these discrepancies may be attributed to the specific anti-catabolic effect of fish oil in preserving loss in protein content that did not occur in the sleep deprived rats. Nevertheless, Papaconstantinou et al [53] reported no difference in body weight of control rats but a larger reduction for fish oil fed rats, exaggerating the sleep deprivation stress-induced weight loss. In this sense, the high fat diet used in this study could act as an extra stressor effect leading to a marked loss of weight. Further, high fat diet increased TNF- $\alpha$ gene expression in adipose tissue of rats [54]. Collectively, high fat diet predispose for insulin resistance, even the source of fat $[55,56]$, suggesting that fish oil can be also harmful if offered in high doses.

To surrogate indexes for insulin sensitivity/resistance we measured the insulin and glucose concentrations under 12 hours of fasting condition and also after a glucose load. We found a higher glycemia, as well as glucose impaired in non sleep deprived rats when compared to PSD rats. A glucose tolerance test without previous anesthesia was performed after repeated restrain and showed no difference in serum concentrations of glucose, while the insulin was higher when compared to the control [57]. A determinant limitation of the current study is that glucose tolerance test was performed in anesthetized animals. Since all groups have been under the same procedure, the biological effect may be attributed to direct effect of sleep loss on serum analysis. Of note, future studies should be conducted in order to address this issue in unanesthetized rats. Recently, using multiple modified platform technique, Hipolide et al [47] found lower insulin levels in PSD male rats. Thus, insulin levels may also being influenced by other external stressors events.

The major finding of the present study was the reduction in adiponectin retroperitoneal adipose tissue gene expression in PSD rats when compared to control rats, not accompanied by alterations in epididymal adipose tissue for adiponectin and TNF- $\alpha$ and/or serum adiponectin levels. In addition, the fish oil diet did not prevent this impaired effect induced by sleep deprivation. These data suggest that the fat content in normolidic diet was not sufficient to regulate adiponectin expression or maybe the period of treatment of 45 days was not long enough to result in improvement. Pighin et al [29] reversed the whole body peripheral insulin sensitivity with 60 days of a normolipidic fish oil in insulin resistance rats. 
A

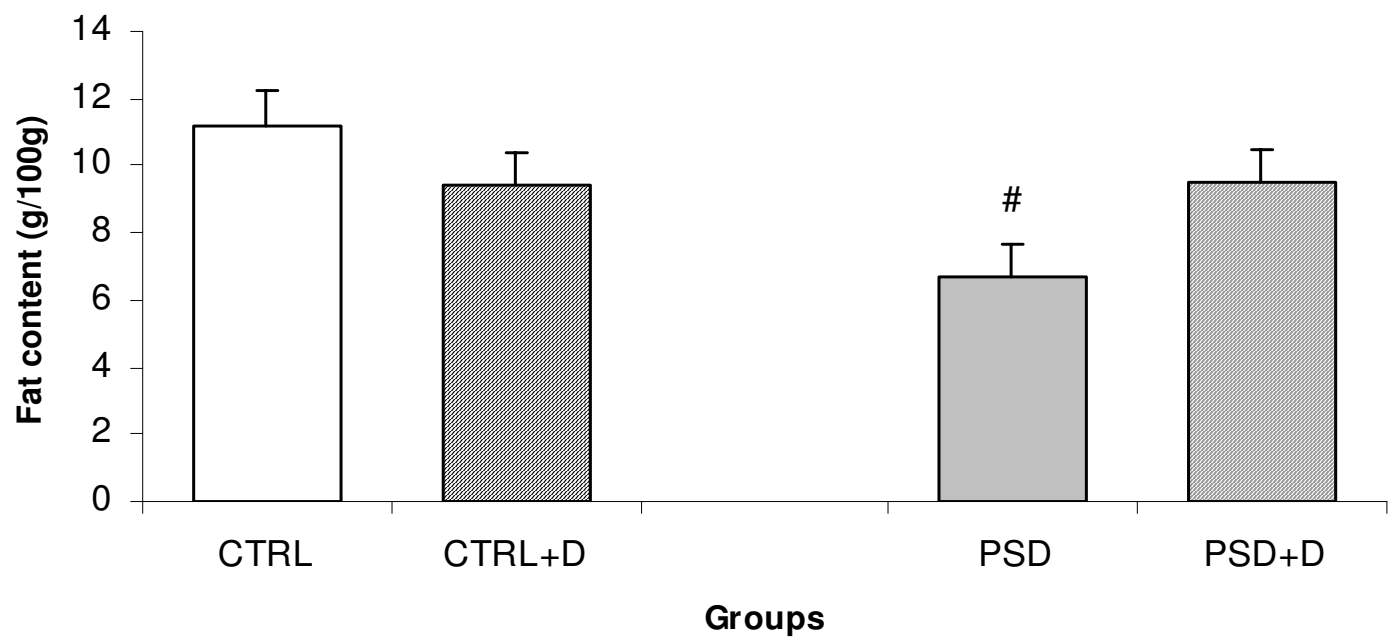

B

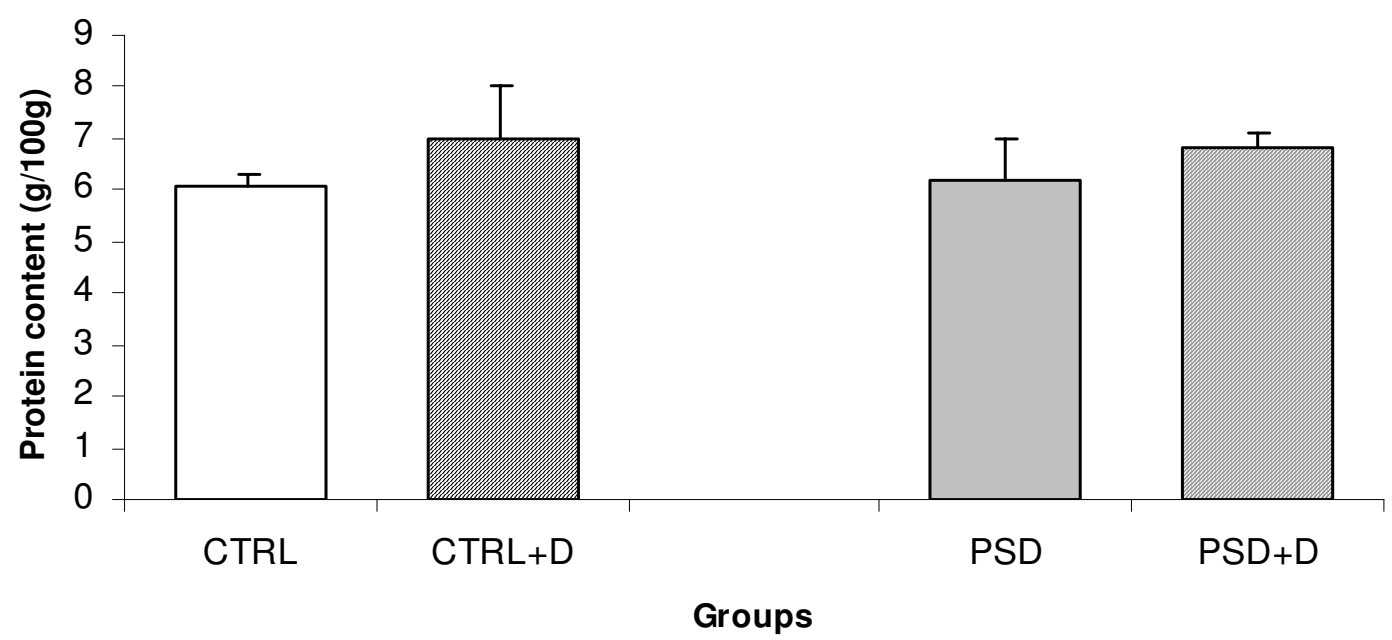

Figure 2

(A) Carcass lipid content ( $\mathrm{n}=9$ animals/group) and (B) protein content ( $\mathbf{n}=\mathbf{5}$ animals/group) in CTRL and PSD rats fed with control or fish oil rich diet. Data are expressed as mean \pm SEM. \#Different from all other groups. 


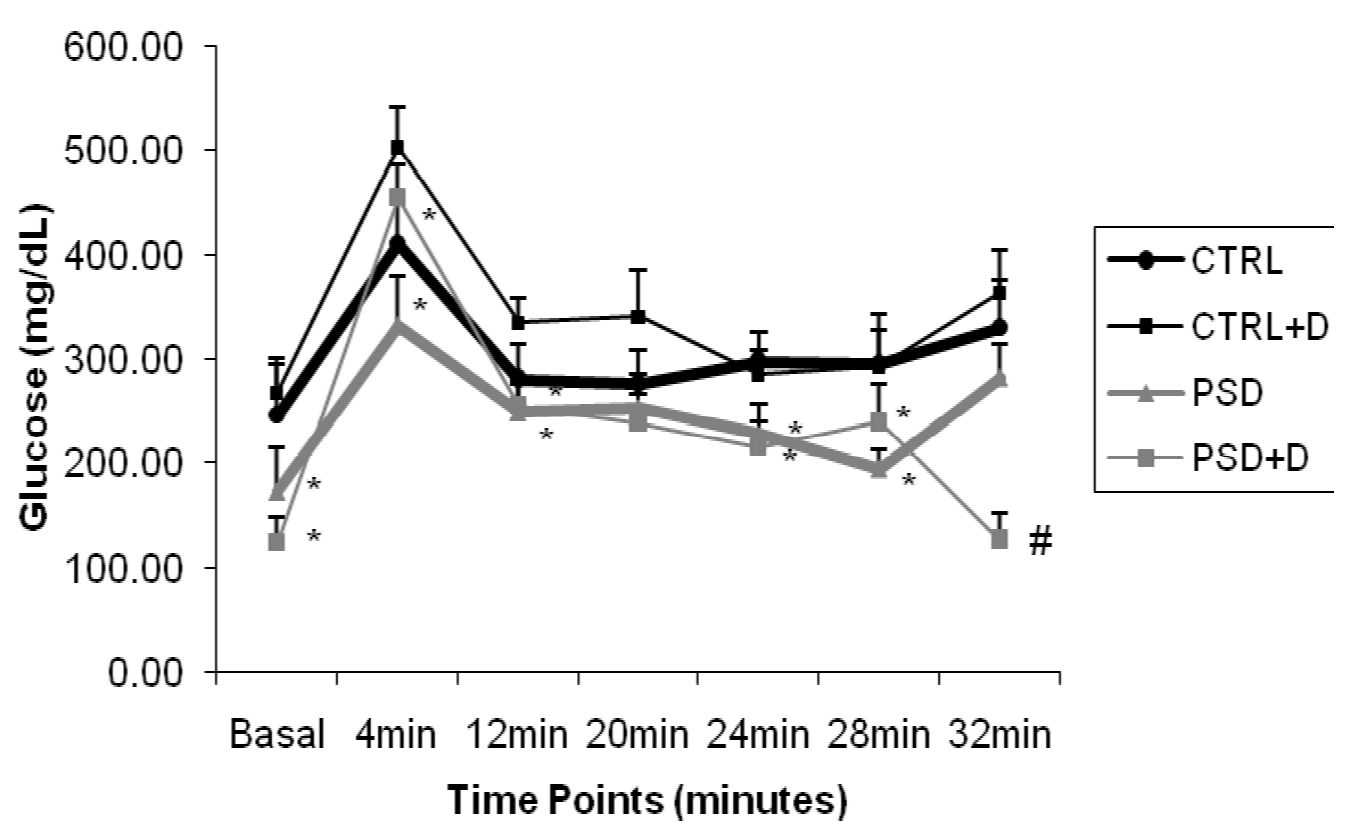

Figure 3

Glucose tolerance test in CTRL and PSD rats fed with control or fish oil rich diet. Data are expressed as mean \pm SEM. *Different from respective CTRL rats ( $n=8-9$ animals/group). \#Different from all other groups.

Adiponectin expression and serum levels decrease with obesity and are positively associated with weigh loss [58]. In contrast, Yamauchi et al [59] showed that adiponectin is decreased in lipoatrophic rats. Thus, its gene expression regulation remains unclear, but studies have shown that TNF- $\alpha$ and glucocorticoids decrease adiponectin gene transcription [60-62].

The dynamics of circulating adiponectin was analyzed in humans showing that the $24 \mathrm{~h}$ serum adiponectin variations followed those of cortisol with a $2 \mathrm{~h}$ lag period later during the day and at night [63]. These authors hypothesized that the nocturnal cortisol decline, indirectly determines compensatory adiponectin changes that would tend to keep the degree of insulin resistance stable. The results maybe explain why the serum adiponectin did not have the same reduction of gene expression in PSD rats, and suggest that more time would be necessary for changings in dynamic variation of cortisol rather to provoke direct action in serum adiponectin. Furthermore, another study focusing fasting state, had no difference in serum adiponectin while the gene expression was reduced, supposing that the large concentration in blood may serve to buffer this hormone against any sudden rise or fall in response to an acute internal or external signal [64].

Interestingly, when analyzing to the comparative physiology of these systems to humans, there is a main important effect of sleep deprivation on adiponectin gene expression programming besides the presence of obesity. Thus, our data showed, as a whole, that sleep deprivation leads to a significant decrease in adiponectin gene expression, which cannot be prevented by a rich fish oil diet. It seems that the stress induced by PSD leads to an impairment in adiponectin gene expression function of retroperitoneal adipose tissue, showing a specific insulin sensitivity negative impact on an adipose tissue depot, independently of weight loss seen in PSD rats.

\section{Competing interests}

The authors declare they have no competing interests.

\section{Authors' contributions}

ABMM have made substantial contributions to conception and design, all the experimental analysis and acquisition of data and also analysis and interpretation of data. MJSP carried out the immunoassays and in the insulin receptor analyze. CO participated in all molecular and biochemical analyzes. CB participated in all molecular and biochemical analyzes. EBR participated in the design of the study and helped to draft the manuscript. CMON participated in the design of the study and performed the statistical analysis. MLA participated in the design of the study and performed the statistical analysis and helped to draft the manuscript. ST participated in the design of the study and performed the statistical analysis and helped to 


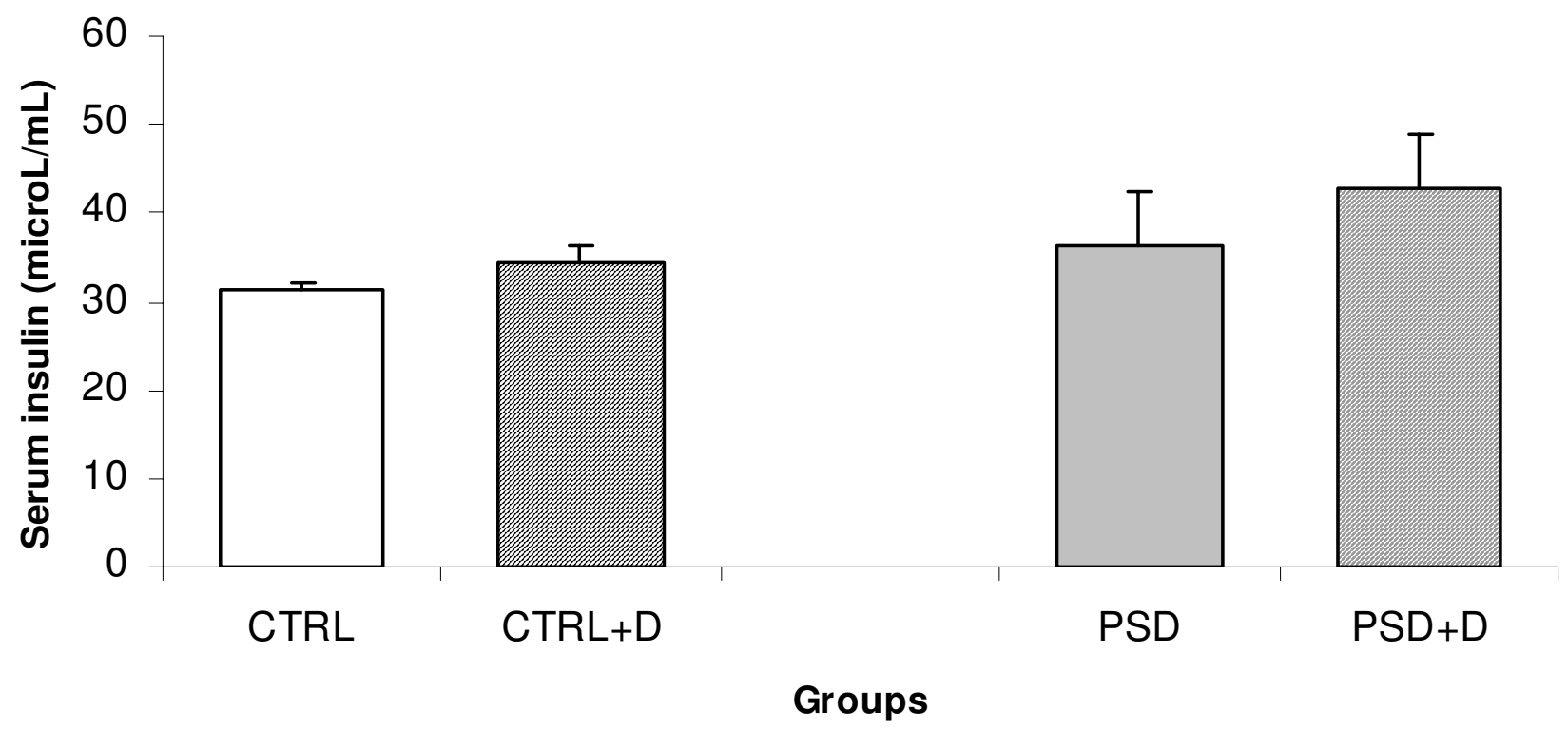

Figure 4

Serum insulin ( $n=5-9$ animals/group) in CTRL and PSD rats fed with normal or fish oil rich diet. Data are expressed as mean \pm SEM.

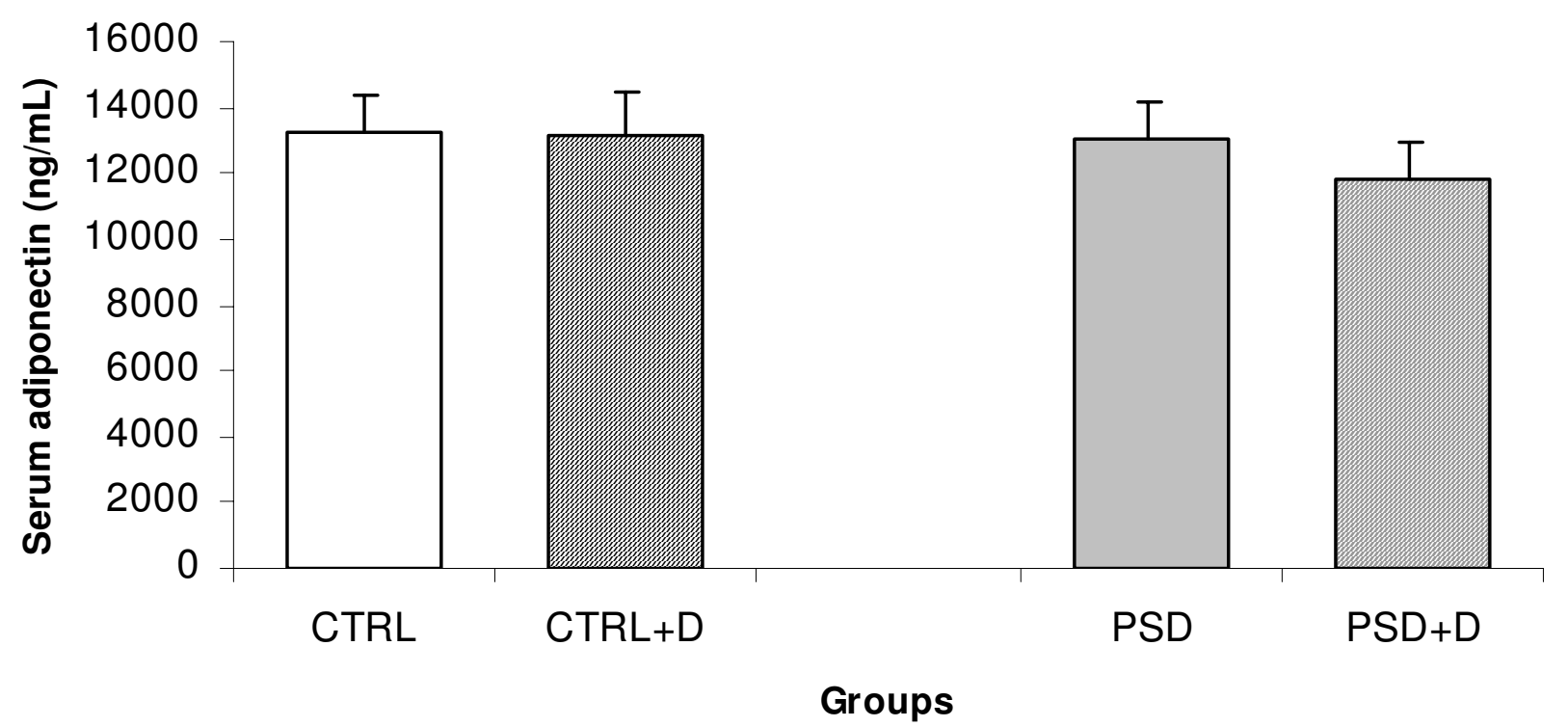

Figure 5

Serum adiponectin ( $n=8$ animals/group) in CTRL and PSD rats fed with normal or fish oil rich diet. Data are expressed as mean \pm SEM. 
A

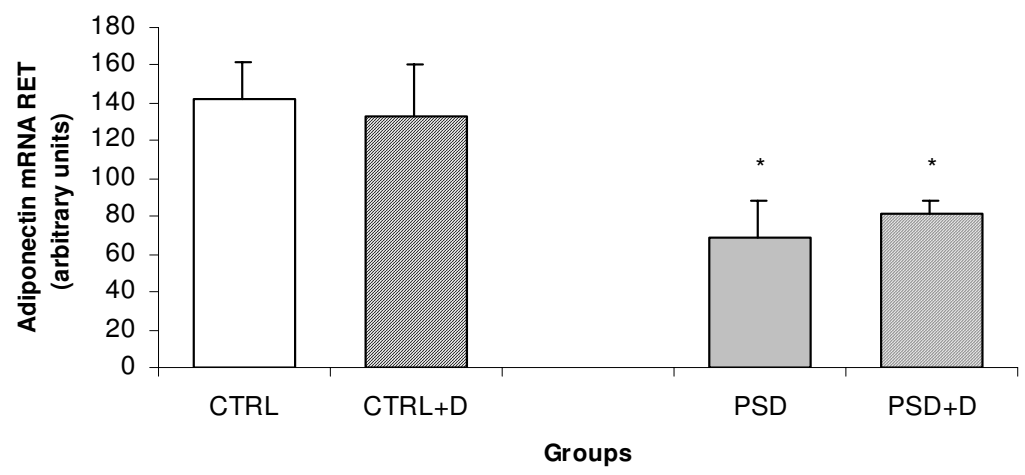

B

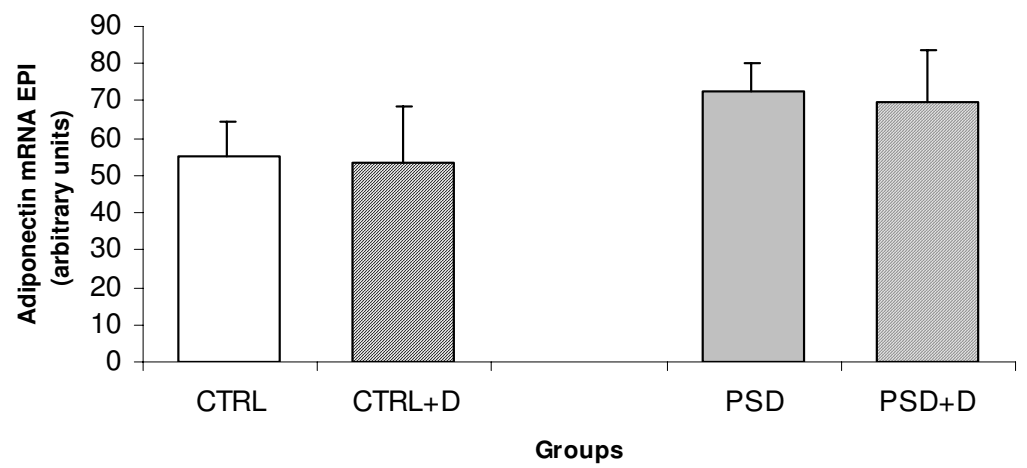

C

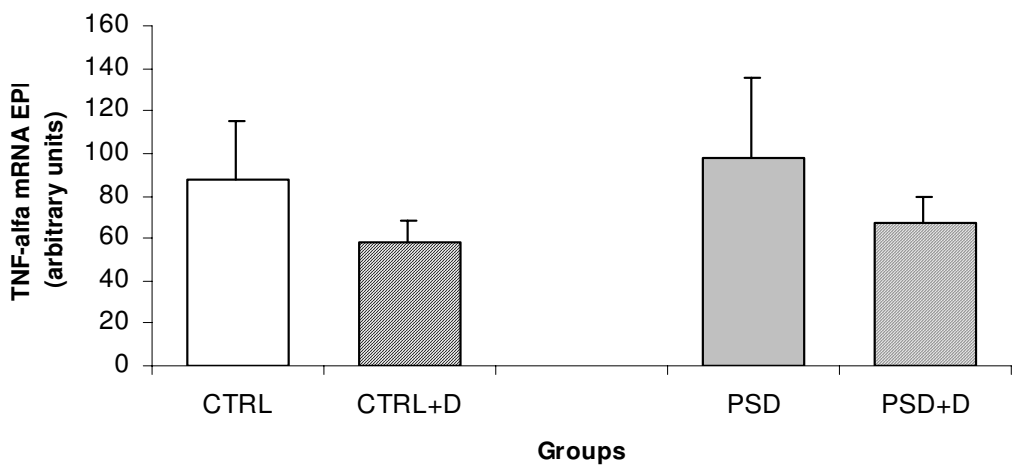

Figure 6

(A) Retroperitoneal adipose tissue adiponectin mRNA expression ( $n=7-8$ animals/group); (B) epididymal adipose tissue adiponectin mRNA expression ( $n=7-9$ animals/group); (C) epididymal adipose tissue TNF- $\alpha$ mRNA expression ( $n=8-9$ animals/group) in CTRL and PSD rats fed with normal or fish oil diet. Data are expressed as mean \pm SEM. *Different from CTRL rats. 
draft the manuscript. LMO has made substantial contributions to conception and design, analysis and interpretation of data and coordination to draft the manuscript.

\section{Acknowledgements}

The authors gratefully acknowledge the invaluable assistance of Mauro Cardoso Pereira for the animal care and Conselho Nacional de Desenvolvimento Científico e Tecnológico (CNPq) for the financial support (\#135165/ 2006-7). This work was also supported by grants from Associação Fundo de Incentivo à Psicofarmacologia (AFIP) and FAPESP (CEPID $n^{\circ}$. 98/I43033 to S.T.). MLA, CMON, EBR and ST are recipients of CNPq fellowship.

\section{References}

I. Leibowitz SM, Lopes MC, Andersen ML, Kushida CA: Sleep deprivation and sleepness caused by sleep loss. Sleep Med Clin 2006, I:3I-45.

2. Spiegel K, Leproult R, van Cauter E: Impact of sleep debt on metabolic and endocrine function. Lancet 1999, 357:1435-39.

3. Spiegel K, Knutson K, Leproult R, Tasali E, van Cauter E: Sleep Loss: a novel risk for insulin resistance an type 2 diabetes. J Appl Physiol 2005, 99:2008-2019.

4. Vgontzas AN, Zoumakis E, Bixler EO, Follett H, Kales A, Chrousos GP: Adverse Effects of Modest Sleep Restriction on Sleepness, Performance, and Inflammatory Cytokines. J Clin Endocrinol Metab 2004, 89:2I I 9-2I26.

5. van Cauter E, Knutson K, Leproult R, Spiegel K: The Impact of Sleep Deprivation on Hormones and Metabolism. Medscape Neurology \& Neurosurgery 2005, 7(I):

6. van Cauter E, Holmback U, Knutson K, Leproult R, Miller A, Nedeltcheva A, Pannain S, Penev P, Tasali E, Spiegel K: Impact of sleep and sleep loss on neuroendocrine and metabolic function. Horm Res 2007, 67(I):2-9.

7. Knutson KL, Spiegel K, Penev P, van Cauter E: The metabolic consequences of sleep deprivation. Sleep Med Rev 2007, II(3): 163-78.

8. Tasali E, Leproult R, Ehrmann DA, van Cauter E: Slow-wave sleep and the risk of type 2 diabetes in humans. PNAS 2008, 105: 1044-1049.

9. Yaggi $H K$, Araujo $A B$, Mckinlay JB: Sleep duration as a risk factor for the development of type 2 diabetes. Diabetes Care 2006, 29:657-661.

10. Bass J, Turek FW: Sleepless in America: A Pathway to Obesity and the Metabolic Syndrome? Arch Intern Med 2005, 165:15-16.

II. Ogawa Y, Kanbayashi T, Saito Y, Takahashi Y, Kitajima T, Takahashi K, Hishikawa Y, Shimizu T: Total sleep deprivation elevates blood pressure through arterial baroreflex resetting: a study with microneurographic technique. Sleep 2003, 26(8):986-9.

12. Takase B, Akima T, Satomura K, Ohsuzu F, Mastui T, Ishihara M, Kurita $A$ : Effects of chronic sleep deprivation on autonomic activity by examining heart rate variability, plasma catecholamine, and intracellular magnesium levels. Biomedicine \& Pharmacotherapy 2004, 58:S35-S39.

13. Dallman MF, Strack AM, Akana SF, Bradbury MJ, Hanson ES, Scribner KA, Smith M: Feast and famine: critical role of glucocorticoids with insulin in daily energy flow. Front Neuroendocrinol 1993, I 4(4):303-47.

14. Leproult R, Copinschi G, Buxton O, van Cauter E: Sleep loss results in an elevation of cortisol levels the next evening. Sleep 1997 , 20(10):865-70.

15. McEwen BS: Protective and damaging effects of stress mediators. N Engl J Med 1998, 338:17|-I79.

16. Andersen ML, Bignotto M, Machado RB, Tufik S: Different stress modalities result in distinct steroid hormone responses by male rats. Braz J Med Biol Res 2004, 37:79I-7.

17. Andersen ML, Martins PJ, D'Almeida V, Bignotto M, Tufik S: Endocrinological and catecholaminergic alterations during sleep deprivation and recovery in male rats. J Sleep Res 2005, 1 4:83-90.

18. Spiegel K, Leproult R, L'Hermite-Balériaux M, Copinschi G, Penev PD, van Cauter E: Leptin Levels Are Dependent on Sleep Duration: Relationships with Sympathovagal Balance, Carbohydrate Regulation, Cortisol, and Thyrotropin. I Clin Endocrinol Metab 2004, 89(I I):5762-5771.
19. Reaven GM, Lithell H, Landsberg L: Hypertension and associated metabolic abnormalities - The role of insulin resistance and the sympathoadrenal system. N Engl J Med 1996, 334:374-382.

20. Nilsson PM, Roost M, Engstrom G, Hedblad B, Berglund G: Incidence of diabetes in middle-aged men is related to sleep disturbances. Diabetes Care 2004, 27:2464-2469.

2I. Ayas NT, White DP, Al-Delaimy WK, Manson JE, Stampfer MJ, Speizer FE, Patel S, Hu FB: A Prospective Study of Self-Reported Sleep Duration and Incident Diabetes in Women. Diabetes Care 2003, 26:380-384.

22. Meisinger $\mathrm{C}$, Heier $\mathrm{M}$, Loewel $\mathrm{H}$ : Sleep disturbance as a predictor of type 2 diabetes mellitus in men and women from the general population. Diabetologia 2005, 48:235-24I.

23. Mallon L, Broman JE, Hetta J: High Incidence of Diabetes in Men With Sleep Complaints or Short Sleep Duration. Diabetes Care 2005, 28:2762-2767.

24. Gottlieb DJ, Punjabi NM, Newman AB, Resnick HE, Redline S, Baldwin CM, Nieto: Association of Sleep Time With Diabetes Mellitus and Impaired Glucose Tolerance. Arch Intern Méd 2005, 165:863-868.

25. Flint J, Kothare SV, Zihlif M, Suarez E, Adams R, Legido A, De Luca F: Association between inadequate sleep and insulin resistance in obese children. I Pediatr 2007, I 50(4):364-9.

26. Martins RC, Andersen ML, Tufik S: The reciprocal interaction between sleep and type 2 diabetes mellitus: facts and perspectives. Braz J Med Biol Res 2008, 4 I (3): | 80-187.

27. Storlien LH, Kraegen EW, Chisholm DJ, Ford GL, Bruce DG, Pascoe WS: Fish oil prevents insulin resistance induced by high-fat feeding in rats. Science 1987, 237:885-888.

28. Taouis M, Dagou C, Ster C, Durand G, Pinault M, Delarue J: N-3 Plynsaturated fatty acids prevent the defect of insuin receptor signaling muscle. Am J Physiol Endocrinol Metab 2002, 282(3):E664-E67I.

29. Pighin D, Karabatas L, Rossi A, Chicco A, Basabe JC, Lombardo YB: Fish oil affects pancreatic fat storage, pyruvate dehydrogenase complex activity, and insulin secretion in rats fed a sucrose-rich diet. J Nutr 2003, I33:4095-4 I0I.

30. Rossi AS, Lombardo YB, Lacorte JM, Chicco AG, Rouault C, Slama G, Rizkalla SW: Dietary fish oil positively regulates plasma leptin and adiponectin levels in sucrose-fed, insulin-resistant rats. Am J Physiol Regul Integr Comp Physiol 2005, 289(2):R486-R494.

31. Neschen S, Morino K, Rossbacher JC, Pongratz RL, Cline GW, Sono S, Gillum M, Shulman GI: Fish oil regulates adiponectin secretion by a peroxisome proliferator-activated receptor-ydependent mechanism in mice. Diabetes 2006, 55:924-928.

32. Neschen S, Morino K, Dong J, Wang-Fischer Y, Cline GW, Romanelli AJ, Rossbacher JC, Moore IK, Regittnig W, Munoz DS, Kim JH, Shulman GI: N-3 Fatty Acids Preserve Insulin Sensitivity In Vivo in a Peroxisome Proliferator-Activated Receptor- $\alpha$-Dependent Manner. Diabetes 2007, 56:1034-1041.

33. Flachs P, Mohamed-Ali V, Horakova O, Rossmeisl M, HosseinzadehAttar MG, Hensler M, Ruzickova J, Kopecky J: Polyunsaturated fatty acids of marine origin induce adiponectin in mice fed a high-fat diet. Diabetologia 2006, 49(2):394-7.

34. Andersen ML, D'Almeida V, Ko GM, Kawakami PJF, Magalhães LE, Tufik S: Ethical and Practical Principles on the Use of Laboratory Animals. São Paulo, Brazil: Universidade Federal de São Paulo; 2004.

35. Reeves PG: Components of the AIN-93 diets as improvements in the AIN-76A dieta. J Nutr 1997, I27(5 Suppl):838S-84IS.

36. Andersen ML, Martins PJ, D'Almeida V, Santos RF, Bignotto M, Tufik $S$ : Effects of paradoxical sleep deprivation on blood parameters associated with cardiovascular risk in aged rats. Exp Gerontol 2004, 39:817-24.

37. Antunes IB, Andersen ML, Alvarenga TA, Tufik S: Effects of paradoxical sleep deprivation on blood parameters associated with cardiovascular risk in intact and ovariectomized rats compared with male rats. Behav Brain Res 2007, 76:187-92.

38. Stansbie D, Denton RM, Bridges BJ, Pask HT, Randle PJ: Regulation of pyruvate dehydrogenase and pyruvate dehydrogenase phosphate phosphatase activity in rat epididymal fat-pads. Effects of starvation, alloxan-diabetes and high-fat diet. Biochem J 1976, I54(I):225-36.

39. Oller do Nascimento CM, Williamson DH: Evidence for conservation of dietary lipid in the rat during lactation and the imme- 
diate period after removal of the litter. Biochem J 1986, 239:233-236.

40. Lowry OH, Rosebrough NJ, Farr AL, Randall RJ: Protein measurement with Folin phenol reagent. I Biol Chem 195I, 1 93(I):265-75.

41. Livak KJ, Schmittgen TD: Analysis of relative gene expression data using real-time quantitative PCR and the 2(-Delta Delta C(T)) Method. Methods 200I, 25(4):402-8.

42. Kushida CA, Bergmann BM, Rechtschaffen A: Sleep deprivation in the rat: IV. Paradoxical sleep deprivation. Sleep 1989, I 2(I):22-30

43. Everson CA, Bergmann BM, Rechtschaffen A: Sleep deprivation in the rat: III. Total sleep deprivation. Sleep 1989, I 2(I): |3-2I.

44. Everson CA, Wehr TA: Nutritional and metabolic adaptations to prolonged sleep deprivation in the rat. Am J Physiol 1993 264(2 Pt 2):R376-R387.

45. Suchecki D, Lobo LL, Hipolide DC, Tufik S: Increased ACTH and corticosterone secretion induced by different methods of paradoxical sleep deprivation. J Sleep Res 1988, 7(4):276-8I.

46. Hanlon EC, Andrzejewski ME, Harder BK, Kelley AE, Benca RM: The effect of REM sleep deprivation on motivation for food reward. Behav Brain Res 2005, 163(1):58-69.

47. Hipolide DC, Suchecki D, Pinto APC, Faria EC, Tufik S, Luz J: Paradoxical sleep deprivation and sleep recovery: effects on the hypothalamic-pituitary-adrenal axis activity, energy balance and body composition of rats. I Neuroendocrinol 2006, | 8(4):23|-8.

48. Martins PJ, D'Almeida $\mathrm{V}$, Nobrega JN, Tufik S: A reassessment of the hyperphagia/weight-loss paradox during sleep deprivation. Sleep 2006, 29(9): I 233-8.

49. Andersen ML, Bignotto B, Tufik S: Influence of paradoxical sleep deprivation and cocaine on development of spontaneous penile reflexes in rats of different ages. Brain Res 2003, 968: $130-8$.

50. Martins PJ, D'Almeida V, Nobrega JN, Tufik S: Sleep deprivationinduced gnawing-relationship to changes in feeding behavior in rats. Physiol Behav 2008, 93(I-2):229-34.

5I. Singer P, Richter-Heinrich E: Stress and fatty liver-possible indications for dietary long-chain n-3 fatty acids. Med Hypotheses |99|, 36(I):90-4.

52. Whitehouse AS, Smith HJ, Drake JL, Tisdale MJ: Mechanism of Attenuation of Skeletal Muscle Protein Catabolism in Cancer Cachexia by Eicosapentaenoic Acid. Cancer Res 200I, 61:3604-3609.

53. Papakonstantinou E, Ryan DH, Harris RB: Dietary fish oil does not protect rats exposed to restraint or sleep deprivation stress. Physiol Behav 2003, 78(4-5):759-65.

54. Morin CL, Eckel RH, Marcel T, Pagliassotti MJ: High Fat Diets Elevate Adipose Tissue-Derived Tumor Necrosis Factor- Activity. Endocrinology 1997, 138:4665.

55. Kim JY, Nolte LA, Hansen PA, Han DH, Ferguson K, Thompson PA Holloszy JO: High-fat diet-induced muscle insulin resistance: relationship to visceral fat mass. Am J Physiol Regulatory Integrative Comp Physiol 2000, 279:2057.

56. Hu FB, Dam RM, Liu S: Diet and risk of type II diabetes: the role of types of fat and carbohydrate. Diabetologia 200I, 44:805-8I7.

57. Zhou J, Yan X, Ryan DH, Harris RBS: Sustained effects of repeated restraint stress on muscle and adipocyte metabolism in high-fat-fed rats. Am J Physiol 1999, 277(3 Pt 2):R757-R766.

58. Yang WS, Lee WJ, Funahashi T, Tanaka S, Matsuzawa $Y$, Chao CL, Chen CL, Tai TY, Chuang LM: Weight Reduction Increases Plasma Levels of an Adipose-Derived Anti-Inflammatory Protein, Adiponectin. J Clin Endocrinol Metab 200I, 86:38I5-38I9.

59. Yamauchi T, Kamon J, Waki H, Kubota N, Hara K, Mori Y, Ide T, Murakami K, Tsuboyama-Kasaoka N, Ezaki O, Akanuma Y, Gavrilova O, Vinson C, Reitman ML, Kagechika H, Shudo K, Yoda M, Nakano Y, Tobe K, Nagai R, Kimura S, Tomita M, Froguel P, Kadowaki T: The fat-derived hormone adiponectin reverses insulin resistance associated with both lipoatrophy and obesity. Nat Med 200I. 7(8):94I-6.

60. Halleux CM, Takahashi M, Delporte ML, Detry R, Funahashi T, Matsuzawa $Y$, Brichard SM: Secretion of adiponectin and regulation of apMI gene expression in human visceral adipose tissue. Biochem Biophys Res Commun 200I, 288(5): I I 02-7.
61. Fasshauer M, Paschke R: Regulation of adipocytokines and insulin resistance. Diabetologia 2003, 46:1594-1603.

62. Frayn KN, Karpe F, Fielding BA, Macdonald IA, Coppack SW: Integrative physiology of human adipose tissue. Int J Obes Relat Metab Disord 2003, 27(8):875-88.

63. Gavrila A, Peng CK, Chan JL, Mietus JE, Goldberger AL, Mantzoros CS: Diurnal and Ultradian Dynamics of Serum Adiponectin in Healthy Men: Comparison with Leptin, Circulating Soluble Leptin Receptor, and Cortisol Patterns. J Clin Endocrinol Metab 2003, 88:2838-2843.

64. Zhang Y, Matheny M, Zolotukhin S, Tumer N, Scarpace PJ: Regulation of adiponectin and leptin gene expression in white and brown adipose tissues: influence of beta3-adrenergic agonists, retinoic acid, leptin and fasting. Biochim Biophys Acta 2002 , I 584(2-3): I I5-22.
Publish with Biomed Central and every scientist can read your work free of charge

"BioMed Central will be the most significant development for disseminating the results of biomedical research in our lifetime. "

Sir Paul Nurse, Cancer Research UK

Your research papers will be:

- available free of charge to the entire biomedical community

- peer reviewed and published immediately upon acceptance

- cited in PubMed and archived on PubMed Central

- yours - you keep the copyright
BioMedcentral 